\title{
Correction: Secondary dispersal driven by overland flow in drylands: Review and mechanistic model development
}

\author{
Sally E Thompson 1* Shmuel Assouline ${ }^{2}$, Li Chen ${ }^{3}$, Ana Trakhtenbrot ${ }^{4}$, Tal Svoray ${ }^{5}$ and Gabriel Katul ${ }^{4,6}$
}

\section{Correction}

After publication of this work [1], we noted that we inadvertently misspelled the name of author Dr. Ana Trakhtenbrot. Here, the author list is updated to reflect the correct spelling of Dr. Trakhtenbrot's name.

\begin{abstract}
Author details
'Department of Civil and Environmental Engineering, UC Berkele, Berkeley, California 94720, USA. ${ }^{2}$ Soil, Water and Environmental Sciences, A.R.O. Volcani Center, Bet Dagan 50250, Israel. ${ }^{3}$ Division of Hydrologic Sciences, Desert Research Center, Las Vegas, NV 89119, USA. ${ }^{4}$ Nicholas School of the Environment, Duke University, Box 90328, Durham, North Carolina 27708, USA. ${ }^{5}$ Geography and Environmental Development, Ben-Gurion University of the Negev, Beer Sheva, Israel. ${ }^{6}$ Pratt School of Engineering, Duke University, Durham, North Carolina 27708, USA.
\end{abstract}

Received: 23 June 2014 Accepted: 25 June 2014

Published online: 22 August 2014

\section{Reference}

1. Thompson SE, Assouline S, Chen L, Trahktenbrot A, Svoray T, Katul GG: Secondary dispersal driven by overland flow in drylands: review and mechanistic model development. Movement Ecology 2014, 2:7. doi:10.1186/2051-3933-2-7

\section{doi:10.1186/s40462-014-0014-5}

Cite this article as: Thompson et al:: Correction: Secondary dispersal driven by overland flow in drylands: Review and mechanistic model development. Movement Ecology 2014 2:14.

\footnotetext{
* Correspondence: sally.thompson@berkeley.edu

'Department of Civil and Environmental Engineering, UC Berkele, Berkeley,
} California 94720, USA

\section{Submit your next manuscript to BioMed Central and take full advantage of: \\ - Convenient online submission \\ - Thorough peer review \\ - No space constraints or color figure charges \\ - Immediate publication on acceptance \\ - Inclusion in PubMed, CAS, Scopus and Google Scholar \\ - Research which is freely available for redistribution \\ Submit your manuscript at www.biomedcentral.com/submit}

